Universidad de Lima

Facultad de Derecho

Carrera de Derecho

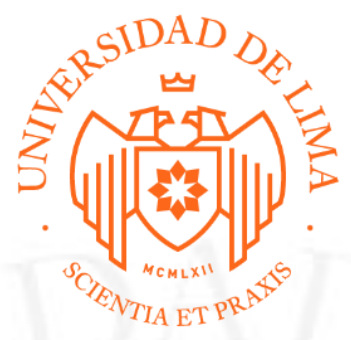

\title{
CIVIL: "DIVORCIO POR CAUSAL" Y LABORAL: "REPOSICIÓN"
}

Trabajo de suficiencia profesional para optar el Título Profesional de Abogado

\author{
Diego Ernesto Torres Minchan
}

Código 20101928

Lima - Perú

Octubre de 2019 


\section{CIVIL: "DIVORCIO POR CAUSAL"}

Materia: Divorcio por Causal

Nro. de Expediente: 365-2010-0-1801-JR-FC-06

\section{RESUMEN}

Se trata de una demanda de divorcio por causal de separación de hecho, en la cual el demandante solicita que se disuelva el vínculo matrimonial y se dé por fenecida la sociedad de gananciales desde la fecha de separación de hecho.

\section{LABORAL: "REPOSICIÓN"}

Materia: Reposición

Nro. de Expediente: 8172-2013-0-1801-JR-LA-03

\section{RESUMEN}

Se trata de un proceso laboral en el que se busca determinar la existencia de la vulneración de voluntad a través de la coacción por parte del empleador contra un trabajador para suscribir una carta de renuncia. 